\title{
FUNCTIONAL ION MEMBRANES SUPPORTED INSIDE MICROPOROUS POLYPROPYLENE MEMBRANES TO TRANSPORT CHROMIUM IONS. DETERMINATION OF MASS TRANSPORT COEFFICIENT
}

\author{
YESID TAPIERO, BERNABÉ L. RIVAS*, JULIO SÁNCHEZ \\ Polymer Department, Faculty of Chemistry, University of Concepcion, Casilla 160-C, Concepcion, Chile.
}

\begin{abstract}
Polypropylene (PP) membranes incorporating interpenetrating polymer networks of poly[(ar-vinylbenzyl) trimethylammonium chloride $](\mathrm{P}(\mathrm{ClVBTA}))$ and poly[sodium (styrenesulfonate)] P(SSNa) were modified via an "in-situ" radical polymerization synthesis inside the pores. The modified polypropylene membranes were characterized using SEM, ATR/FTIR, DRX, TGA, and Donnan dialysis for the transport of chromium ions. The modified membranes exhibited a percent modification between $2.5 \%$ and $4.0 \%$ in weight gain and a hydrophilic character with a water uptake capacity between $15 \%$ and $20 \%$. The mass transport coefficient was determined using the non-linear fit of the experimental data to the exponential equation. Hexavalent chromium ions were efficiently transported by the modified membranes containing P(ClVBTA). At pH 3.0, the M4Cl.PEI $\left(11.0 \times 10^{-6} \mathrm{~m} \mathrm{~s}^{-1}\right)$, and at $\mathrm{pH} 9.0$, the $\mathrm{M} 3 \mathrm{Cl}\left(14.4 \times 10^{-6} \mathrm{~m} \mathrm{~s}^{-1}\right)$ could transport hexavalent chromium ions efficiently using a $1 \mathrm{~mol} \mathrm{~L}^{-1} \mathrm{NaCl}$ extraction agent. In the same way, the transport of trivalent chromium could be performed using membranes modified with $\mathrm{P}(\mathrm{SSNa})$. At $\mathrm{pH} 3.0$ and $4.0 \times 10^{-2} \mathrm{~mol} \mathrm{~L}^{-1}$ trivalent chromium in the food chamber, the M9Na.PVA $\left(16.3 \times 10^{-6} \mathrm{~m} \mathrm{~s}^{-1}\right)$ performed efficient transport using $1 \times 10^{-3} \mathrm{~mol} \mathrm{~L}^{-1} \mathrm{HNO}_{3}$ as the extraction agent.
\end{abstract}

Keywords: interpenetrating polymer network, membranes, Donnan dialysis, chromium, ion exchange, and polypropylene.

\section{INTRODUCTION}

Environmental pollution of water, soil, and air is a serious problem when it includes oxyanions. Some oxyanion water-contaminating species employed in industry are chromate, arsenate, permanganate, hydrogen selenite, and selenate. A particular case is the derivatives of the chromium oxyanions. Chromium ions have two oxidation states in the water, for example, the trivalent chromium $\mathrm{Cr}(\mathrm{III})$ and hexavalent chromium $\mathrm{Cr}(\mathrm{VI})$.

$\mathrm{Cr}(\mathrm{VI})$ produces the oxyanion (chromate) and the polyoxyanion (dichromate). These oxyanions are the more toxic ionic species and cause serious health problems such as cancer. The toxicity depends on the concentration and the exposure period ${ }^{1,2}$. Cr(VI) oxyanions are water-soluble across all $\mathrm{pH}$ ranges and accumulate well in biological systems (bioassimilable), and their speciation depends on the $\mathrm{pH}$ and concentration. If the $\mathrm{pH}$ is strongly acidic and the $\mathrm{Cr}(\mathrm{VI})$ ions are highly concentrated, the chromium ions exist as dichromate $\left(\mathrm{Cr}_{2} \mathrm{O}_{7}^{2-}\right)$, chromic acid $\left(\mathrm{H}_{2} \mathrm{CrO}_{4}\right)$, and dichromate acid $\left(\mathrm{H}_{2} \mathrm{Cr}_{2} \mathrm{O}_{7}\right)^{3,4}$. However, at weakly acidic $\mathrm{pH}$ values above 6.0 , a large quantity of chromate $\left(\mathrm{CrO}_{4}{ }^{2-}\right)$ ions exists, and in the range of $\mathrm{pH}$ values between 4.0 and 6.0, dichromate $\left(\mathrm{Cr}_{2} \mathrm{O}_{7}^{2-}\right)$, and chromate $\left(\mathrm{CrO}_{4}^{2-}\right)$ ions can exist. The World Health Organization (WHO) recommends a maximum concentration limit of $0.05\left(\mathrm{mg} \mathrm{L}^{-1}\right)^{5}$ by the hexavalent chromium ions.

However, the $\mathrm{Cr}(\mathrm{III})$ ion is an element essential for life $^{6}$. Nevertheless, at certain concentrations, the $\mathrm{Cr}(\mathrm{III})$ ion can cause biological damage. The main $\mathrm{Cr}(\mathrm{III})$ species that dissolves in water depends on the $\mathrm{pH}$ range, and the ions are $\mathrm{Cr}(\mathrm{OH})_{2}^{+}, \mathrm{Cr}(\mathrm{OH})_{3}{ }^{0}$, and $\mathrm{Cr}(\mathrm{OH})_{4}{ }^{-}$chromyl ions, which prevail at $\mathrm{pH}$ values below $3.6^{7}$. When the $\mathrm{pH}$ values are higher, $\mathrm{Cr}(\mathrm{III})$ precipitates as $\mathrm{Cr}(\mathrm{OH})_{3} \times \mathrm{nH}_{2} \mathrm{O}^{8}$.

The most common methods developed to remove $\mathrm{Cr}(\mathrm{VI})$, and $\mathrm{Cr}(\mathrm{III})$ ions from polluted solutions are reduction and precipitation ${ }^{9}$, adsorption ${ }^{10}$, and ion exchange ${ }^{11,12}$. Membrane technologies allow for reverse osmosis, ultrafiltration, nanofiltration, dialysis, diffusion dialysis, Donnan dialysis, membrane electrolysis, and electrodialysis, ${ }^{4-12}$ (liquid, emulsified and supported) ${ }^{13,15,16}$. However, it is difficult to eliminate the oxyanions $\mathrm{Cr}(\mathrm{VI})$ and the $\mathrm{Cr}(\mathrm{III})$ ions selectively from the water. The improvement of the removal methods and the production of new functional polymer materials are very useful in the development of new technologies for removal, retention, and recovery of the chromium ions from aqueous solutions. Donnan dialysis using the ion exchange membranes has been considered as an alternative for the separation process.

The Donnan dialysis technique is based on the employment of the chemical potential differences between the membrane sides to generate ionic transport and to maintain the electro neutrality of the two solutions, and the Donnan dialysis is considered a hybrid process ${ }^{17}$. The efficient Donnan dialysis process depends on selecting a suitable working membrane. The main applications are in areas such as chemical analysis for pre-concentration, for extraction processes, for hydrometallurgy ${ }^{18}$, for separating acids from their salts $^{19,20}$, for deacidification of radioactive flow $^{21}$, for removing copper and zinc using commercial cationic membranes ${ }^{22}$, for removing inorganic anions such as fluoride, nitrate, bromate, and borate from drinking water ${ }^{14,19,23}$ and for removing $\mathrm{Cr}(\mathrm{VI})$ ions using commercial anion exchange membranes such as SB-6470, AFN, ACM, and Raipore 1030 18,24,25.

Generally, the Donnan dialysis employs the functional membranes that are ideally developed from chemically stable commercial porous materials. An alternative for the modification of some porous supports is interpenetration of polymer network (IPN) synthesis ${ }^{26,27}$. Some samples of commercial disposable micro-porous membranes are polypropylene (PP) or polyethylene ${ }^{23}$.

The IUPAC classification of an interpenetrating polymer network (IPN) architecture is "Polymer comprising two or more networks that are at least partially interlaced on a molecular scale but not covalently bonded to each other and cannot be separated unless chemical bonds are broken"26-28. The goal of the IPN material is the combination of physicochemical properties of individual functional polymers in the same material. The IPNs materials have been used in different scientific areas as; ion exchange materials ${ }^{29}$, proton exchange membranes ${ }^{30}$, alkaline fuel cell membranes ${ }^{31}$, functional membranes by the diffusion dialysis ${ }^{32}$, among others.

The main goal of this work was to modify polypropylene membranes for the "in-situ" synthesis of the interpenetrating poly[(arvinylbenzyl) trimethylammonium chloride], $\mathrm{P}(\mathrm{ClVBTA})$ and poly[sodium (styrenesulfonate)], $\mathrm{P}(\mathrm{SSNa})$ networks with the capacity to transport $\mathrm{Cr}(\mathrm{VI})$ and $\mathrm{Cr}(\mathrm{III})$ ions via Donnan dialysis.

\subsection{Theoretical}

For the Donnan dialysis experiments, the following equations were employed to analyze the data. The different experimental systems can be considered as a pseudo-steady state process where the mass transfer $\left(\mathrm{k}_{\mathrm{m}}\right)$ across the membrane was assumed to be in a steady state during all experiments. Thus, the Donnan membrane mass transfer dialysis can be described by Fick's first law (see eq. 1). A linear concentration gradient across the membrane was assumed. The flux of ions through exchange membranes can be represented by equation 1:

$$
\begin{aligned}
& J_{i}=\frac{H \times K \times \varepsilon \times D_{S}}{\tau \times \delta} \times \Delta C_{i} \\
& k_{m}=\frac{H \times K \times \varepsilon \times D_{S}}{\tau \times \delta}
\end{aligned}
$$


Where $J i$, is the solute flux, $\Delta \mathrm{Ci}$, is the concentration gradient, $H$, is the fraction of available area, $K$, is the solute partition coefficient, $\varepsilon$, is the porosity of the membrane, $D s$, is the solute diffusion coefficient inside the pores of the membrane, $\tau$, is the membrane tortuosity, $\delta$, is the membrane thickness, and $\mathrm{km}$, is the mass transfer coefficient (see eq. 2).

$$
J_{i}=k_{m} \times \Delta C_{i}
$$

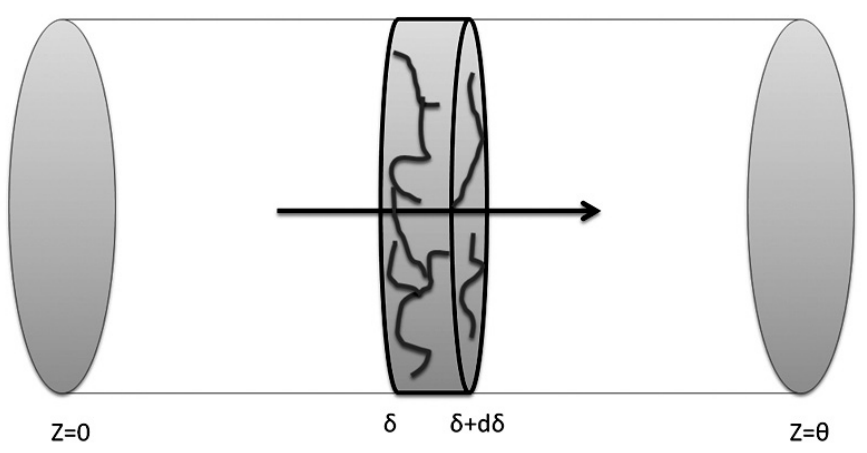

Figure 1. Ion mass transfer through a membrane system in the $\mathrm{z}$ direction. The mass balance equation over a differential element of width $\Delta \mathrm{z}$ and cross-sectional area $\mathrm{A}_{\mathrm{c}}$ for the extraction chamber is given in equation 4 (see Figure 1):

$$
V_{e, c} \times \frac{d C_{i, e}}{d t}=A_{c} \times\left. J_{i, \delta}\right|_{\delta+d \delta}
$$

Where Ve,c, is the volume of the extraction chamber $(100 \mathrm{~mL}), A c$, is the effective membrane area $(5 \mathrm{~cm} 2), \mathrm{t}$ is the time $(\mathrm{min})$, and Ci,e, is the concentration of the $(\mathrm{Cr}(\mathrm{VI})$, or $\mathrm{Cr}(\mathrm{III})$, or NO3-) inside the extraction chamber. Combining the equations 3 and 4 , integrating by $\mathrm{Ci}$,e, from time zero to t, and rearranging the combined equation yields equation 5 :

$$
C_{i, e}=\frac{C_{i, f}^{0}}{2} \times\left\{1-e^{\frac{-2 \times A_{c}}{V_{e, c}} \times k_{m} \times t}\right\}
$$

Where $C 0 i, f$, is the concentration of the $(\mathrm{Cr}(\mathrm{VI})$, or $\mathrm{Cr}(\mathrm{III})$, or NO3-) inside the food chamber at time zero.

\section{EXPERIMENTAL}

\subsection{Reagents and materials}

Sodium styrenesulfonate (SSNa, Aldrich), Ar-[(vinylbenzyl) trimethylammonium chloride] (ClVBTA, Aldrich), ammonium persulfate (APS, Merck), and $N, N^{\prime}$-methylene bis acrylamide (MBA, Aldrich) were used for the (IPN) synthesis.

Microporous isotactic PP membranes were employed $(0.6-\mu \mathrm{m}$ pore size, AN06 Merck Millipore) (MPP). The other reagents used were: glutaraldehyde (Ga) (Aldrich), $15 \mathrm{kDa}$ polyvinyl alcohol (PVA, Merck), 15 $\mathrm{kDa}$ poly(ethyleneimine) (PEI, Aldrich), divinylsulfone(Aldrich), $200 \mathrm{kDa}$ (P(SSNa), Aldrich), ethanol (Merck), and Type I deionized water from Thermo Fisher TKA Scientific. A stirred-cell filtration unit (Millipore, model 8050) was used to inject the reactive solution pressure into the PP porous membrane. An aluminum flat reactor was used for the radical polymerization. A UB-10 $\mathrm{pH} / \mathrm{mV}$ meter from Denver Instrument was used to measure the $\mathrm{pH}$ solution. A dielectric barrier discharge (DBD) plasma reactor was used to activate the membrane surfaces; the components and operating modes of the DBD have previously been published ${ }^{33}$.

$\mathrm{K}_{2} \mathrm{Cr}_{2} \mathrm{O}_{7}$ (Merck) and $\mathrm{Cr}\left(\mathrm{NO}_{3}\right)_{3} \times 9 \mathrm{H}_{2} \mathrm{O}$ (Merck) were the chromium sources. $\mathrm{NaCl}$ was the extraction reagent, and the $\mathrm{NaNO}_{3}$ (Merck) was used for the binary system. $\mathrm{HCl}$ (Merck), $\mathrm{HNO}_{3}$ (Merck), and $\mathrm{NaOH}$ (Merck) were used to control the $\mathrm{pH}$.

2.2 Synthesis of $\mathrm{P}(\mathrm{CIVBTA})$ and $\mathrm{P}(\mathrm{SSNa})$ interpenetrating polymer networks

The membranes were washed with an aqueous mixture of $50 \% \mathrm{w} / \mathrm{w}$ ethanol to eliminate all of the wastes and wet the pores. A stirred-cell filtration unit was employed with nitrogen gas and a pressure of 100kPas. Reaction solution (functional monomer (CIVBTA or SSNa), crosslinking reagent (MBA), and initiator reagent (APS), and $10 \mathrm{~mL}$ of water as a solvent) was passed through the membrane. The moisturized membranes with the reactive solution inside the pores were carried to the flat reactor by the free radical polymerization.

Other method is the plasma activation process. Both sides of the polypropylene membrane contacted the argon plasma for $1 \mathrm{~min}$. Then, the active membrane contacted the reactive solution (CIVBTA or SSNa, MBA, and APS), and diffuse inside the pores. This process was performed inside an Erlenmeyer flask under an inert argon atmosphere.

Table 1 shows the experimental design for the IPN formation. The "insitu" free-radical polymerization was performed inside the membrane pores at $70^{\circ} \mathrm{C}$ for $24 \mathrm{~h}$. Ammonium persulfate $(1 \mathrm{~mol} \%)$ was used as the radical generation reagent. The polymerization reaction was carried out fast due to it is necessary to decrease the drain reactive solution, low yield of reaction, and the phase separation. The samples were dried in an oven at $50^{\circ} \mathrm{C}$ and stored in a silica dryer for $24 \mathrm{~h}$.

Table 2, shows the modified $\mathrm{P}(\mathrm{ClVBTA})$ IPN membranes, that were treated using a functional solution $(15 \mathrm{kDa}$ PEI $(5 \% \mathrm{w} / \mathrm{w}))$, at room temperature for $12 \mathrm{~h}$. Then, these membranes were submerged in an aqueous $\mathrm{Ga}(5 \% \mathrm{w} / \mathrm{w})$ solution. Additionally, Table 2 shows the modified P(CIVBTA) IPN membranes that were treated using a functional solution (15 kDa PVA $(5 \% \mathrm{w} / \mathrm{w}))$ at room temperature for $12 \mathrm{~h}$. At the next step, the membranes were contacted with a $1 \mathrm{~mol} \mathrm{~L}^{-1}$ divinylsulfone and sodium carbonate mixture. Both processes occurred over $12 \mathrm{~h}$ to produce the polyelectrolyte crosslinking. Finally, the membranes were washed four times with water. The samples were dried in an oven at $50^{\circ} \mathrm{Cand}$ left in silica dryer for $24 \mathrm{~h}$.

\subsection{Characterization}

The percent modification $\left(\% \mathrm{P}_{\mathrm{Mi}}\right)$ was gravimetrically measured and determined from equation 6 . The dry membrane samples (unmodified and modified IPNs) were weighed again after the modification process. This method quantitatively calculated the mass percent of the hydrophilic IPN.

$$
\% P_{M i}=\frac{\left(w_{f}-w_{0}\right)}{w_{0}} \times 100 \%
$$

Where wf is the dry IPN membrane weight $(\mathrm{g})$, and w0 is the unmodified membrane weight (g).

The water uptake percent $\left(\% \mathrm{~W}_{w i}\right)$ was calculated from equation 7 . The weights of the dry modified IPN membrane samples were measured before wetting with distilled deionized water for $24 \mathrm{~h}$ at room temperature.

$$
\% W_{w i}=\frac{\left(W_{w e t}-W_{d r y}\right)}{W_{d r y}} \times 100 \%
$$

Where wwet is the wet IPN membrane weight (g), and wdry is the dry IPN membrane weight ( $\mathrm{g})$.

Microstructural analysis. The surface analysis of the modified and unmodified membranes were analyzed by the Fourier transform infrared spectroscopy coupled to attenuated total reflectance (ATR/IR) (Nicolet FTIR equipment with a DTGS-KBr detector (Omnic 5.2 Nicolet instrument Corp.)), and the scanning electron microscope (SEM) (20,000 KV JEOL microscope (JSH 6380LV model)) to identify the main functional groups and morphological and structural changes.

Change of phases. The modified and unmodified membrane phases were characterized by X-ray diffraction (XRD), using a Bruker AXS D4 Endeavor diffractometer (Germany), with $\mathrm{Cu} \mathrm{K} \alpha$ radiation $(\lambda=1.5406 \AA)$, a scan rate of $0.4 \% \mathrm{~min}$, and operated at $40 \mathrm{kV}$ and $20 \mathrm{~mA}$.

Thermal gravimetric analysis (TGA). This method was developed usingthethermobalance TG209 Iris F1® model equipment. All experiments were performed under a nitrogen gas atmosphere with a heating rate of $10^{\circ} \mathrm{C} /$ min, in a temperature range between $30^{\circ} \mathrm{C}$ to $550^{\circ} \mathrm{C}$, employing a $250 \mathrm{~mL} / \mathrm{min}$ flow rate of nitrogen gas. The membrane samples weighed between 5 to $10 \mathrm{mg}$, and an aluminum saucer was used as a reference. This technique was employed to determine the decomposition temperature of the membranes.

$\mathrm{Cr}(\mathrm{VI})$ and $\mathrm{Cr}$ (III) ion mass transport and Donnan dialysis evaluation.

The mass transfer of $\mathrm{Cr}(\mathrm{VI})$ ions through the modified IPN pore membranes at $\mathrm{pH} 3.0$ and 9.0 was examined. A two-chamber diffusion cell (feed and extraction phases) was used, and the chambers were separated by a membrane. Each chamber had a $100 \mathrm{~mL}$ capacity and was filled with $50 \mathrm{~mL}$ of 
the working solution for the tests. The diffusion cell used in this study is described in Figure 1. The concentration polarization effect was neglected because of a sufficiently high stirring speed in each cell chamber.

Table 1.Experimental design of the interpenetrating polymer networks (IPN) synthesis inside pores polypropylene membranes.

\begin{tabular}{|c|c|c|c|c|c|}
\hline Sample code & $\begin{array}{c}\mathrm{N}^{0} \text { of } \\
\text { Injections }\end{array}$ & $\begin{array}{c}\text { Plasma } \\
\text { activation }\end{array}$ & $\begin{array}{c}\text { Monomer } \\
\text { mol L L }^{-1}\end{array}$ & $\underset{\%}{\operatorname{MBA}}$ & Polymer Network \\
\hline $\mathrm{M} 1 \mathrm{Cl}$ & 3 & --- & $1.9 \times 10^{-1}$ & 2 & \multirow{7}{*}{$\mathrm{P}(\mathrm{ClVBTA})$} \\
\hline $\mathrm{M} 2 \mathrm{Cl}$ & 3 & --- & $3.8 \times 10^{-1}$ & 2 & \\
\hline $\mathrm{M} 3 \mathrm{Cl}$ & 1 & --- & $5.7 \times 10^{-1}$ & 2 & \\
\hline $\mathrm{M} 4 \mathrm{Cl}$ & 1 & --- & $3.8 \times 10^{-1}$ & 6 & \\
\hline M5ClP & 1 & --- & $3.8 \times 10^{-1}$ & 8 & \\
\hline M6ClP & 1 & --- & $3.8 \times 10^{-1}$ & 6 & \\
\hline M7Clplasma & --- & 1 & $3.8 \times 10^{-1}$ & 6 & \\
\hline $\mathrm{M} 8 \mathrm{Na}$ & 3 & --- & $3.8 \times 10^{-1}$ & 2 & \multirow{6}{*}{$\mathrm{P}(\mathrm{SSNa})$} \\
\hline M9Na & 1 & --- & $3.8 \times 10^{-1}$ & 6 & \\
\hline $\mathrm{M} 10 \mathrm{NaP}$ & 1 & --- & $3.8 \times 10^{-1}$ & 8 & \\
\hline $\mathrm{M} 11 \mathrm{NaP}$ & 1 & --- & $3.8 \times 10^{-1}$ & 6 & \\
\hline $\mathrm{M} 12 \mathrm{NaP}$ & 1 & --- & $3.8 \times 10^{-1}$ & 4 & \\
\hline M13Naplasma & --- & 1 & $3.8 \times 10^{-1}$ & 6 & \\
\hline
\end{tabular}

Table 2. Experimental design of the superficial layer formed on the P(ClVBTA), and P(SSNa) membranes.

\begin{tabular}{|c|c|}
\hline Surface layer & Membranes \\
\hline PEI & $\mathrm{M} 1 \mathrm{Cl}, \mathrm{M} 2 \mathrm{Cl}, \begin{array}{c}\mathrm{M} 3 \mathrm{Cl}, \mathrm{M} 4 \mathrm{Cl}, \mathrm{M} 5 \mathrm{ClP}, \mathrm{M} 6 \mathrm{ClP}, \\
\text { M7Clplasma }\end{array}$ \\
\hline PVA & $\mathrm{M} 8 \mathrm{Na}, \mathrm{M} 10 \mathrm{NaP}, \mathrm{M} 11 \mathrm{NaP}, \mathrm{M} 12 \mathrm{NaP}, \mathrm{M} 13$ Naplasma \\
\hline
\end{tabular}

Table 3. Experimental conditions to evaluate the $\mathrm{Cr}(\mathrm{VI})$ and $\mathrm{Cr}(\mathrm{III})$ ions transport.

\begin{tabular}{|c|c|c|c|c|c|c|}
\hline Experiment & {$[\mathrm{Cr}(\mathrm{III})] \mathrm{mol} \mathrm{L}^{-1}$} & {$[\mathrm{Cr}(\mathrm{VI})] \mathrm{mol} \mathrm{L}^{-1}$} & $\mathbf{p H}_{\text {feedphase }}$ & pH- ${ }_{\text {extractionphase }}$ & \multicolumn{2}{|c|}{ Extraction agent $\mathrm{mol} \mathrm{L}^{-1}$} \\
\hline P(CIVBTA) & & & & & \multicolumn{2}{|c|}{$\mathrm{NaCl}$} \\
\hline 1 & --- & $5 \times 10^{-4}$ & 3.0 & 3.0 & 1 & \\
\hline 2 & --- & $5 \times 10^{-4}$ & 9.0 & 9.0 & 1 & \\
\hline P(SSNa) & & & & & $\mathrm{HNO}_{3}$ & $\mathrm{NaCl}$ \\
\hline 3 & $1 \times 10^{-2}$ & --- & 2.0 & 2.0 & $1 \times 10^{-2}$ & --- \\
\hline 4 & $4 \times 10^{-2}$ & --- & 2.0 & 1.0 & $1 \times 10^{-1}$ & --- \\
\hline 5 & $4 \times 10^{-2}$ & --- & 2.0 & 3.0 & $1 \times 10^{-3}$ & --- \\
\hline 6 & $4 \times 10^{-2}$ & --- & 2.0 & 2.0 & $1 \times 10^{-2}$ & 1 \\
\hline
\end{tabular}

Table 3 shows the experimental conditions for the transport study. The modified $\mathrm{P}(\mathrm{ClVBTA})$ IPN membranes were used for $\mathrm{Cr}(\mathrm{VI})$ ion transport, together with the P(ClVBTA) IPN modified membranes with a superficial PEI layer. $\mathrm{The} \mathrm{Cr}(\mathrm{VI})$ solution was put in the feed chamber, and the extraction chamber was filled with a $1 \mathrm{~mol} \mathrm{~L}^{-1} \mathrm{NaCl}$ solution. Every 60 min for 18 to $24 \mathrm{~h}, 3 \mathrm{~mL}$ was extracted from the extraction chamber and was returned to the extraction chamber after reading the $\mathrm{Cr}(\mathrm{VI})$ ion concentration. $\mathrm{The} \mathrm{Cr}(\mathrm{VI})$ concentration is suitable for interacting with the fixed charges in the P(CIVBTA) membrane ${ }^{34}$. Additionally, a binary $\mathrm{Cr}(\mathrm{VI}) / \mathrm{NO}_{3}$ - solution (1:1) was prepared. The transport was analyzed using the $\mathrm{P}(\mathrm{ClVBTA}) \mathrm{IPN}$ membranes. The feed chamber was filled with $5 \times 10^{-4} \mathrm{~mol} \mathrm{~L}^{-1} \mathrm{~K}_{2} \mathrm{Cr}_{2} \mathrm{O}_{7}$ and $1 \times 10^{-1} \mathrm{~mol} \mathrm{~L}^{-1} \mathrm{NaNO}_{3}$, and the solution $\mathrm{pH}$ was 9.0. The extraction reagent was $1 \times 10^{-1} \mathrm{~mol} \mathrm{~L}^{-1} \mathrm{NaCl}$ at $\mathrm{pH}$ 9.0. The extraction reagent was $1 \times 10^{-1} \mathrm{~mol} \mathrm{~L}^{-1} \mathrm{NaCl}$ at $\mathrm{pH} 9.0$. Every $60 \mathrm{~min}$ for 18 to $24 \mathrm{~h}, 3 \mathrm{~mL}$ of the solution was extracted from the extraction chamber.
The transport was analyzed using the $\mathrm{P}(\mathrm{ClVBTA}) \mathrm{IPN}$ membranes.

The modified P(SSNa) IPN membranes were used to study the $\mathrm{Cr}(\mathrm{III})$ ion transport, together with the P(SSNa) IPN membranes with a superficial PVA layer. The $\mathrm{Cr}(\mathrm{III})$ acid solution was put in the feed chamber, and the extraction chamber was filled with the $\mathrm{HNO}_{3}$ solution. Table 3 shows the experimental conditions. Samples were taken from the extraction chamber to measure the $\mathrm{Cr}$ (III) ion concentration. A $3 \mathrm{~mL}$ sample was taken every 60 min for 4 and $6 \mathrm{~h}$ and was returned to the extraction chamber after reading the $\mathrm{Cr}(\mathrm{VI})$ ion concentration. In other experiments, $1 \times 10^{-2} \mathrm{~mol} \mathrm{~L}^{-1} \mathrm{HNO}_{3}$ and $1 \mathrm{~mol} \mathrm{~L}^{-1} \mathrm{NaCl}$ were put in the extraction chamber. The $\mathrm{Cr}(\mathrm{III})$ concentration is suitable for interacting with the fixed charges in the membrane ${ }^{34}$.

All Donnan dialysis experiments were conducted at room temperature. A Cary 100 scan UV-visible spectrophotometer from Varian was used to measure the $\mathrm{Cr}(\mathrm{VI})$ and $\mathrm{Cr}(\mathrm{III})$ ion concentrations directly ${ }^{35}$. The $\mathrm{Cr}(\mathrm{VI})$ ion was 
measured at $350 \mathrm{~nm}$ in a pH 3.0 solution and at $372 \mathrm{~nm}$ in a pH 9.0 solution $^{35}$ The $\mathrm{Cr}$ (III) ion concentration was measured at the wavelengths $407 \mathrm{~nm}$ and $573 \mathrm{~nm}$ for an acid $\mathrm{pH}^{35}$. A wavelength of $301 \mathrm{~nm}$ was used to determine the $\mathrm{NO}_{3}$-ion concentration.

The transport of $\mathrm{Cr}(\mathrm{III}), \mathrm{Cr}(\mathrm{VI})$, and $\mathrm{NO}_{3}^{-}$ions was evaluated based on the mass transfer coefficient $\left(\mathrm{k}_{\mathrm{m}}\right)$ indicated in equation 2 . The mass transfer coefficient $\left(\mathrm{k}_{\mathrm{m}}\right)$ was calculated using the non-linear curve method. The equation 2 was approximated by the non-linear exponential curve as equation 8 :

$$
y=y_{0} \pm A \times e^{R_{0} \times t}
$$

Where $R 0$, is the $(-2 \times A c / V e, c) \times k m, y 0$, is the $C 0 i, f, \mathrm{~A}$, is the $C 0 i, f / 2$, and $\mathrm{y}$ is the Ci,e, of equation 2. Ci,e, is the concentration of $\mathrm{Cr}(\mathrm{VI}), \mathrm{Cr}(\mathrm{III})$, or $\left(\mathrm{NO}_{3}\right)$ in the extraction chamber during the time. COi,f, was the ion concentration in the feed chamber at time 0and could be $\mathrm{Cr}(\mathrm{VI}), \mathrm{Cr}(\mathrm{III})$, or $\mathrm{NO}_{3}$ - The aim of nonlinear fitting is to estimate the parameter values which best describe the data. This method is also called chi-square minimization. It was used the Levenberg-Marquardt (L-M) algorithm to adjust the parameter values in the iterative procedure. This algorithm combines the Gauss-Newton method and the steepest descent method.

\section{RESULTS AND DISCUSSION}

3.1 Synthesis and characterization of the functionalized microporous PP membranes.

Table 4 shows the results of the micro-pore evaluation of the IPN modified and unmodified PP membranes that were developed from changing the percent modification $\left(\% \Delta \mathrm{P}_{\mathrm{Mi}}\right)$ and the water uptake percent $\left(\% \mathrm{~W}_{\mathrm{wi}}\right)$. These results were compared with unmodified PP membrane sample. The $\mathrm{M} 1 \mathrm{Cl}, \mathrm{M} 2 \mathrm{Cl}$, and $\mathrm{M} 3 \mathrm{Cl}$ membranes showed increasing percent modifications, whereas the water uptake percent decreased for these membranes because the functional IPNs produced resistance to the water.

Table 4. Optimum values of modified degree percentage, water uptake percentage, and mass transport coefficient of $\mathrm{Cr}(\mathrm{VI})$ and $\mathrm{Cr}(\mathrm{III})$ ions.

\begin{tabular}{|c|c|c|c|c|c|c|}
\hline \multirow[b]{2}{*}{ Membranescode } & \multirow[b]{2}{*}{$\% \Delta \mathrm{P}_{\mathrm{Mi}}$} & \multirow[b]{2}{*}{$\% \mathrm{~W}_{\mathrm{wi}}$} & \multicolumn{2}{|c|}{$\mathrm{k}_{\mathrm{m}} \times 10^{-6} \mathrm{~m} \mathrm{~s}^{-1}[\mathrm{Cr}(\mathrm{VI})]$} & \multicolumn{2}{|c|}{$\mathrm{k}_{\mathrm{m}} \times 10^{-6} \mathrm{~m} \mathrm{~s}^{-1}[\mathrm{Cr}(\mathrm{III})]$} \\
\hline & & & $\mathrm{pH} 3.0$ & $\begin{array}{l}\mathrm{pH} \\
9.0 \\
\end{array}$ & $\begin{array}{c}\mathrm{pH} 1 \\
\mathrm{HNO}_{3} \\
\end{array}$ & $\mathrm{pH} 2 \mathrm{HNO}_{3} / \mathrm{NaCl}$ \\
\hline $\mathrm{M} 1 \mathrm{Cl}$ & 2.6 & 22.79 & 0.85 & 1.2 & --- & --- \\
\hline $\mathrm{M} 2 \mathrm{Cl}$ & 3.99 & 20.3 & 1.4 & 1.6 & --- & --- \\
\hline $\mathrm{M} 3 \mathrm{Cl}$ & 5.27 & 15 & 4.2 & 14.4 & --- & --- \\
\hline $\mathrm{M} 4 \mathrm{Cl}$ & 3.5 & 15.04 & 2.0 & 1.8 & --- & --- \\
\hline M5ClP & 4.38 & 13.20 & 6.6 & 2.0 & --- & --- \\
\hline M6Cl.P & 3.38 & 22.54 & 1.6 & 1.2 & --- & --- \\
\hline M7Clplasma & 4.1 & 12.5 & 2.3 & 6.9 & --- & --- \\
\hline M8Na & 3.36 & 28.4 & --- & --- & 2.3 & 2.4 \\
\hline M9Na & 2.74 & 19.1 & --- & --- & 8.2 & 7.8 \\
\hline $\mathrm{M} 10 \mathrm{NaP}$ & 3.19 & 18.57 & --- & --- & 2.2 & 2.0 \\
\hline $\mathrm{M} 11 \mathrm{NaP}$ & 2.81 & 16.7 & --- & --- & 3.4 & 3.7 \\
\hline $\mathrm{M} 12 \mathrm{NaP}$ & 3.52 & 19.53 & --- & -- & 10.1 & 13.4 \\
\hline M13Naplasma & 3.53 & 20.4 & --- & --- & 11.9 & 11.3 \\
\hline MPP & --- & --- & 0.4 & 0.8 & 0.1 & 0.1 \\
\hline
\end{tabular}

The percent modification for the $\mathrm{M} 8 \mathrm{Na}(\mathrm{P}(\mathrm{SSNa}) \mathrm{IPN})$ membrane was similar to the percent modification for the $\mathrm{M} 2 \mathrm{Cl}$ (P(CIVBTA) IPN) membrane However, the water uptake percentages were different. Additionally, other comparisons between the percent modification of the $\mathrm{M} 2 \mathrm{Cl}$ and $\mathrm{M} 9 \mathrm{Na}$ membranes were similar values, whereas the percent water uptake was smaller for higher quantities injected (see Table 4).

The highest value for all of the synthesized membranes was achieved by M6ClP and M12NaP semi-IPNs. These differing results occurred because of the $\mathrm{P}(\mathrm{SSNa})$ IPN morphology in the shape of the layer, and the P(ClVBTA) IPNs formed agglomerated amorphous particles (see SEM analyze). The P(SSNa) IPNs went deeper into the PP membrane structure than the P(ClVBTA) IPNs The $\mathrm{P}(\mathrm{ClVBTA})$ IPNs agglomerated in large quantities on the surface, which makes accessing the quaternary ammonium groups easier.

The semi-IPN membranes (M6ClP and M12NaP) exhibited percent modifications and percent water uptake very similar to the membranes synthesized via a superficial activation plasma technique (M7Clplasma and M13Naplasma) (see Table 4). The internal pore structure of polypropylene membrane modified by the "in-situ" synthesis of the functional polymeric network can be considered as an IPN or semi-IPN depending on the crosslinking of the new polymeric network. Generally, the modifications of the polypropylene membranes depend of the percent modification completely. These results do not exceed $5 \%$, due to that they have $30 \%$ of porosity, and the polypropylene fibers which shape the membrane are very compacts. However, the hydrophilic properties of the membranes were changed. Phase separation is expected during the IPN formation due to that the CIVBTA, and SSNa monomers are hydrophilic and polypropylene membrane is very hydrophobic. This behavior can explain the low values of the percent modification.

\subsection{Microstructure analysis}

The microstructure of the modified IPN and unmodified PP membranes was determined using the ATR/FTIR absorption bands of the functional groups. The measurement was performed in the range between $400 \mathrm{~cm}^{-1}$ and $5000 \mathrm{~cm}^{-1}$. Figure 2 shows the ATR/FTIR results for the membranes.

Figure 2a shows the ATR/FTIR MPP spectra. The MPP sample had absorption bands at $2970-2800 \mathrm{~cm}^{-1}$ resulting from the stress and asymmetric stretching of $\mathrm{C}-\mathrm{H}\left(\delta_{\mathrm{as}}\right)$ bonds in the methyl $\left(-\mathrm{CH}_{3}\right)$ groups, and the signals at $1480-1380 \mathrm{~cm}^{-1}$ resulting from the $\mathrm{C}-\mathrm{H}(\delta)$ of $\mathrm{CH}_{2}$ bond flexion vibrations because these bonds have asymmetric scissor deformations. The peak at $1300-700 \mathrm{~cm}^{-1}$ represents the changing isotactic polypropylene microstructural characteristics $^{36,37}$. However, the absorption signals $\left(\vartheta_{\text {as }}\left(-\mathrm{CH}_{2}\right), \delta_{\text {as }}\left(-\mathrm{CH}_{2}\right)\right.$ and $\left.\delta_{s}\left(-\mathrm{CH}_{2}\right)\right)$ were stronger in the modified IPN samples than in the unmodified PP membrane signals (see Figure $2 \mathrm{a}, \mathrm{b}$, and $\mathrm{c}$ ).

Figure $2 \mathrm{~b}$ shows the characteristic absorption bands of the P(ClVBTA) IPN membrane (M5ClP). The signals from $1400-1600 \mathrm{~cm}^{-1}$ represent the aromatic $\mathrm{C}=\mathrm{C}$ absorption signals. The absorption peaks of the quaternary ammonium group are placed at $1581 \mathrm{~cm}^{-1}$ for the N-H bond and C-N vibration and $1483 \mathrm{~cm}^{-1}$ for the $\left(-\mathrm{N}^{+}-\left(\mathrm{CH}_{3}\right)\right)$ group bond flexion. 


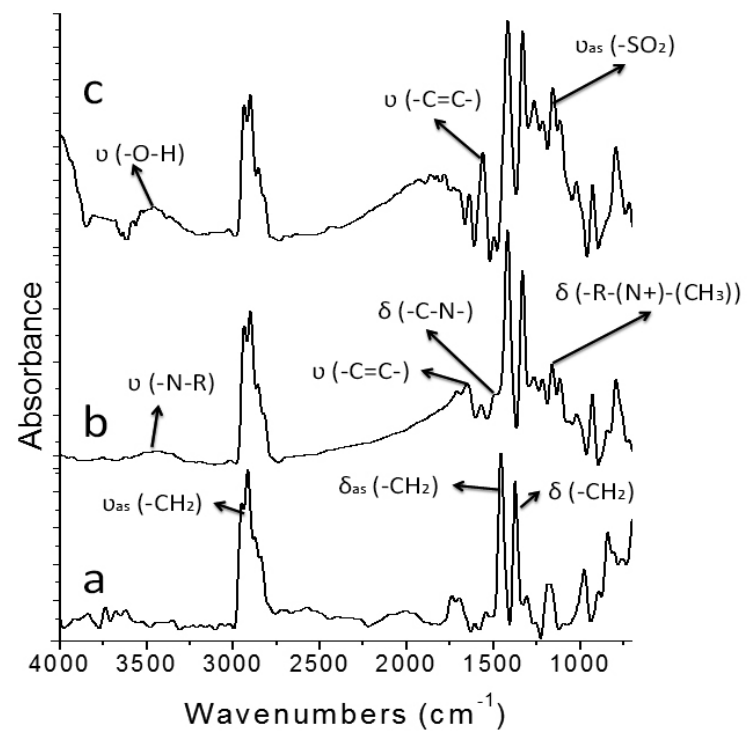

Figure 2. ATR/FTIR spectra of $\mathrm{P}(\mathrm{ClVBTA})$ and $\mathrm{P}(\mathrm{SSNa})$ IPNs and unmodified MPP membranes. a. MPP. b. M5ClP. c. M10NaP.

Figure 2c shows the characteristic absorption bands of the P(SSNa) IPN membrane $(\mathrm{M} 10 \mathrm{NaP})$. The absorption peaks of the $\mathrm{SO}_{3}^{-}$from the sulfonate group are observed at $1042 \mathrm{~cm}^{-1}(\mathrm{~S}=\mathrm{O})$ and $1175 \mathrm{~cm}^{-1}$, and the peaks at $1400-$ $1600 \mathrm{~cm}^{-1}$ correspond to the aromatic $(\mathrm{C}=\mathrm{C})$ carbons.

The morphologic changes were determined using SEM analysis. Figures 3 and 4 show the morphological analysis.
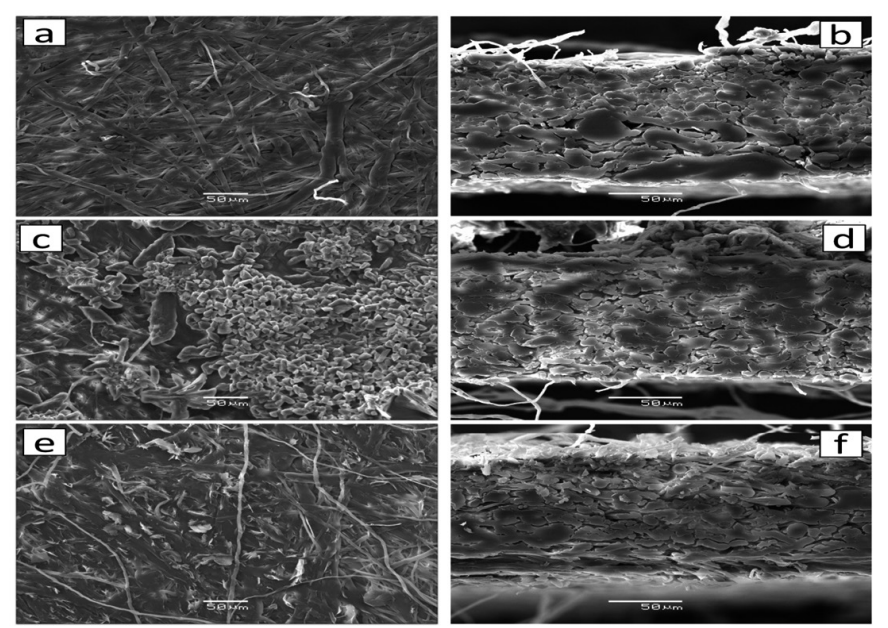

Figure 3. SEM images of the modified and unmodified polypropylene membranes to $50 \mu \mathrm{m}$ and $\times 300$ magnifications. a. MPP surface membrane. b. MPP cross-sectional area membrane. b. $\mathrm{M} 4 \mathrm{Cl}$ surface membrane. c. $\mathrm{M} 4 \mathrm{Cl}$ cross-sectional area membrane. e. M9Na surface membrane. c. M9Na crosssectional area membrane.

Figures $3 \mathrm{a}$ and $\mathrm{b}$ show the morphology and fibers of a unmodified MPP membrane as determined by SEM, and the membrane face had an intertwined fiber structure, low porosity, and a smooth superficial aspect. These results are characteristic of an anisotropic membrane ${ }^{38,39}$. Comparing Figure $3 \mathrm{c}$, $3 \mathrm{e}$ with Figure $3 \mathrm{a}$, the structure of the membrane has been modified by the incorporation of P(ClVBTA) and P(SSNa) IPNs.

Figure $3 \mathrm{c}$ shows the superficial face SEM image of the $\mathrm{M} 4 \mathrm{Cl}$, and two different phases were observed. Figure $3 \mathrm{~d}$ shows the cross-sectional area membrane. This result indicates a change in the microstructural homogeneity comparing the $\mathrm{M} 4 \mathrm{Cl}$ image with respect to the MPP image.

Figure 3e shows the morphology from the superficial face SEM image of the M9Na. Figure 3f shows the cross-sectional area membrane. Two phases can be identified: a phase of the PP fibers and the other phase to ion IPNs of the sulfonate group. The decrease of surface homogeneity of the $\mathrm{M} 4 \mathrm{Cl}$, and M9Na (see Figures 3c and e) can be explained as a result in the possible pore size decrease since the IPN were mainly formed in the inside of the pores. The free volume of the unmodified polypropylene membrane was occupied, at least in good part by the $\mathrm{P}(\mathrm{CIVBTA})$, and $\mathrm{P}(\mathrm{SSNa}) \mathrm{IPN}{ }^{40-42}$.

Figures $3 \mathrm{~d}$, and $3 \mathrm{f}$ of cross-section images, as the mass gain increases respect to the unmodified MPP, the grain-like structure, which indicates the incorporation of $\mathrm{P}(\mathrm{CIVBTA})$ and $\mathrm{P}(\mathrm{SSNa}) \mathrm{IPN}$, becomes denser structure. But due the compact polypropylene fibers the incorporation of $\mathrm{P}(\mathrm{ClVBTA})$ and $\mathrm{P}(\mathrm{SSNa})$ throughout the whole thickness were not uniform ${ }^{42}$.

The polypropylene fibers making up the membranes are very compact, and the cross-sectional area cut indicated that the $\mathrm{P}(\mathrm{ClVBTA})$, and $\mathrm{P}(\mathrm{SSNa})$ IPN presented of something protuberances that came from inner part of IPN structure which showed interconnected pores. These results are the microphase separation from the synthesis.
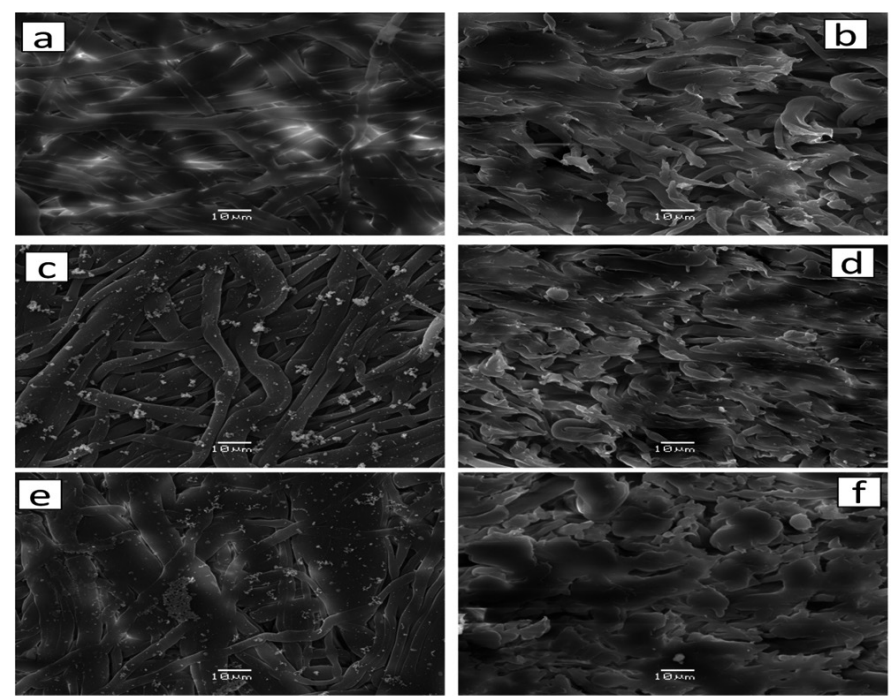

Figure 4. SEM images of the modified and unmodified polypropylene membranes to $10 \mu \mathrm{m}$ and $\times 1000$ magnification. a. MPP surface membrane. b. MPP cross-sectional area membrane. b. M7Clplasma surface membrane. c. M7Clplasma cross-sectional area membrane. e. M13Naplasma surface membrane. c. M13Naplasma cross-sectional area membrane.

Besides, it was analyzed the membrane morphology of M7Clplasma, and M13Naplasma, and they were compared with the membrane morphology MPP (see Figure 4). A decrease of the surface homogeneity was showed from SEM images.

Figures $4 \mathrm{a}$, and $\mathrm{b}$ show the MPP membrane morphology. This morphology is smooth fibers. Figures $4 \mathrm{c}$ and $\mathrm{d}$ show the $\mathrm{M} 7 \mathrm{Cl}$ plasma membrane morphology. On the surface of membrane was formed the P(CIVBTA) IPN, and this material covered the entire PP fiber surface like agglomerated small spheres. The P(CIVBTA) IPN material was more better distributed than the $\mathrm{P}(\mathrm{ClVBTA}) \mathrm{IPN}$ on the $\mathrm{M} 4 \mathrm{Cl}$. Figures $4 \mathrm{e}$ and $4 \mathrm{f}$ show the M13Na plasma membrane morphology. The IPN material in the M13Na plasma is more distributed in all fibers than the M9Na. The $\mathrm{P}(\mathrm{SSNa})$ IPN covered the entire PP fiber surface like a paint in the M13Naplasma and M9Na (see Figure 4e). The $\mathrm{P}(\mathrm{SSNa})$ IPN particle sizes were smaller and less agglomerated in the M13Naplasma, and the M9Na showed smaller particle sizes and appeared less agglomerated than the $\mathrm{P}(\mathrm{ClVBTA})$ IPN $(\mathrm{M} 4 \mathrm{Cl})$. The PP fibers provide support and mechanical resistance to the amorphous IPN materials, and the IPN materials produce the ion exchange. The (P(ClVBTA) and P(SSNa)) IPN former could be the cluster particles formation as a result of the relatively high (MBA) crosslinked concentration ${ }^{43,44}$.

Similar results were obtained when a polypropylene film was superficially modified with $\mathrm{P}(\mathrm{SSNa})$, and a polyethylene film was modified with $\mathrm{P}(\mathrm{SSNa})$. The main results showed a structural surface change where small particles with small pores appeare $\mathrm{d}^{45}$. The grafted and copolymerized 4-vinylpyridinium monomer appeared within the PP membranes with $0.5-\mu \mathrm{m} \operatorname{pores}^{46}$. Poly $(N, N-$ dimethylaminoethyl methacrylate) (PDMAEMA) was grafted and crosslinked onto the PP membrane surface. The membrane had an $80 \%$ porosity with a $0.20-\mu \mathrm{m}$ pore $\operatorname{size}^{47}$. 


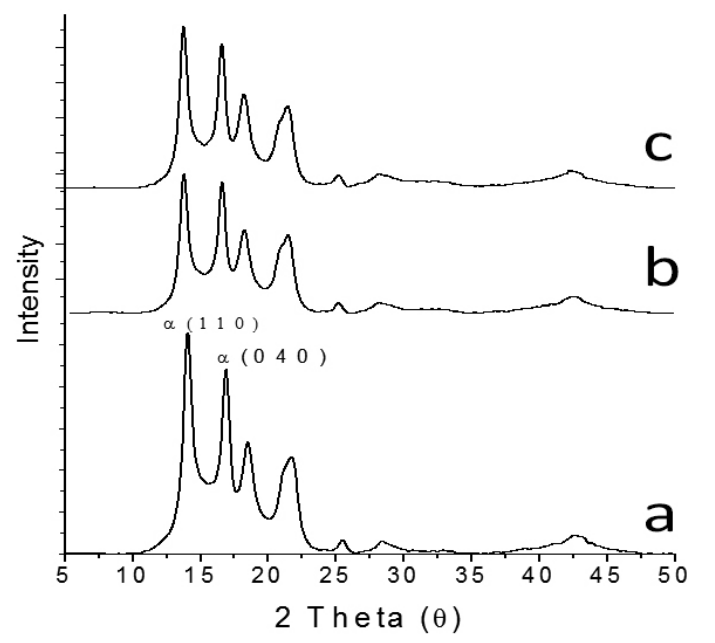

Figure 5. X-Ray diffraction analysis of unmodified and modified IPN membranes. a. MPP. b. M11NaP. c. M6ClP.

Figure 5a shows the characteristic crystalline phases of the MPP membranes, and the monoclinic alpha phase with the reflection on $\alpha(110)$, and $\alpha(040)$, perpendicular to each other ${ }^{48}$. The $\alpha(110)$ intensity values of the M11NaP (3893.28) and the M6ClP (4480.58) are less than the alpha plane intensity values of the MPP. Similarly, the $\alpha(040)$ intensity values of the MPP samples are higher than the M11NaP (3628.61) and the M6ClP (3965.32) (see Figure $5 b$ and $5 c$ ).

The order of the $2 \theta$ values is as follows: $\mathrm{MPP}\left(14^{\circ}\right)>\mathrm{M} 11 \mathrm{NaP}\left(13.73^{\circ}\right)>\mathrm{M} 6$ $\mathrm{CIP}\left(13.71^{\circ}\right)$ by the $\alpha(110)$ plane, and the $\mathrm{MPP}\left(16.79^{\circ}\right)>\mathrm{M} 11 \mathrm{NaP}\left(16.53^{\circ}\right)>\mathrm{M} 6$ $\mathrm{ClP}\left(16.51^{\circ}\right)$ by the $\alpha(140)$ plane. The modified IPNs produce a decrease of the $2 \theta$ value phases in comparison with the MPP.

These results suggested that the $\mathrm{P}(\mathrm{CIVBTA})$ and the $\mathrm{P}(\mathrm{SSNa})$ IPNs are producing changes in the crystallinity of the PP suppor ${ }^{49}$. It is possible that the
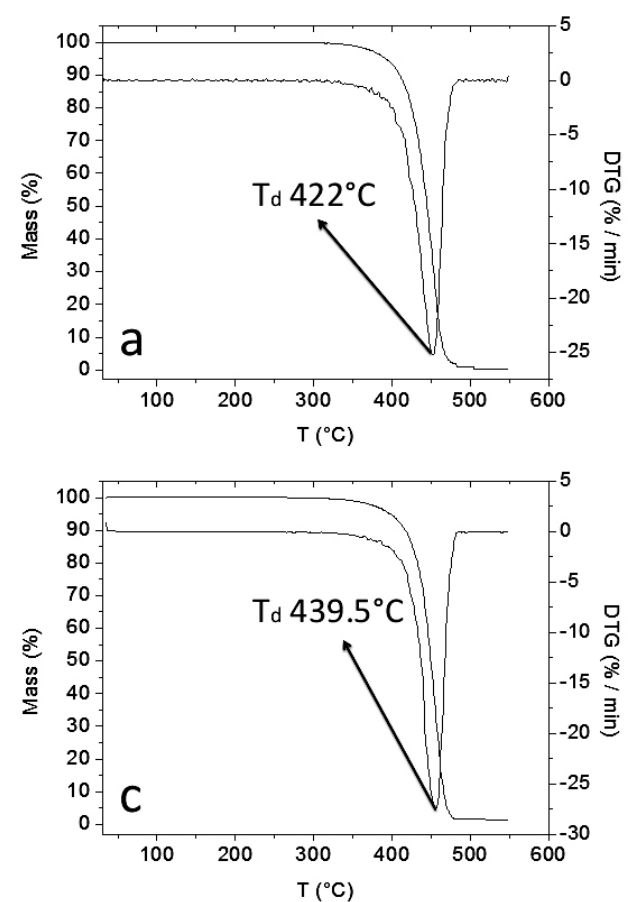

$\mathrm{P}(\mathrm{ClVBTA})$ and the $\mathrm{P}(\mathrm{SSNa})$ were grafted on the polypropylene fibers.

Previous research has shown similar results using DRX analysis. For example, PP and polyethylene films were modified using a polystyrene graft, followed by the sulfonation process. This modified method produces a decrease in the crystallinity of the film ${ }^{50}$.

\subsection{Thermogravimetric(TGA)analysis.}

Figure 6 shows the thermogravimetric curves of the modified IPNs and unmodified PP membranes. All thermogram curves produce a simple thermal decomposition form. These results were produced by the drying process of the samples before being analyzed. The thermal decomposition of the isotactic PP started in the range between $150^{\circ} \mathrm{C}$ and $220^{\circ} \mathrm{C}^{51,52}$ (see Figure 6a). The residual mass percentage was $0.089 \%$.
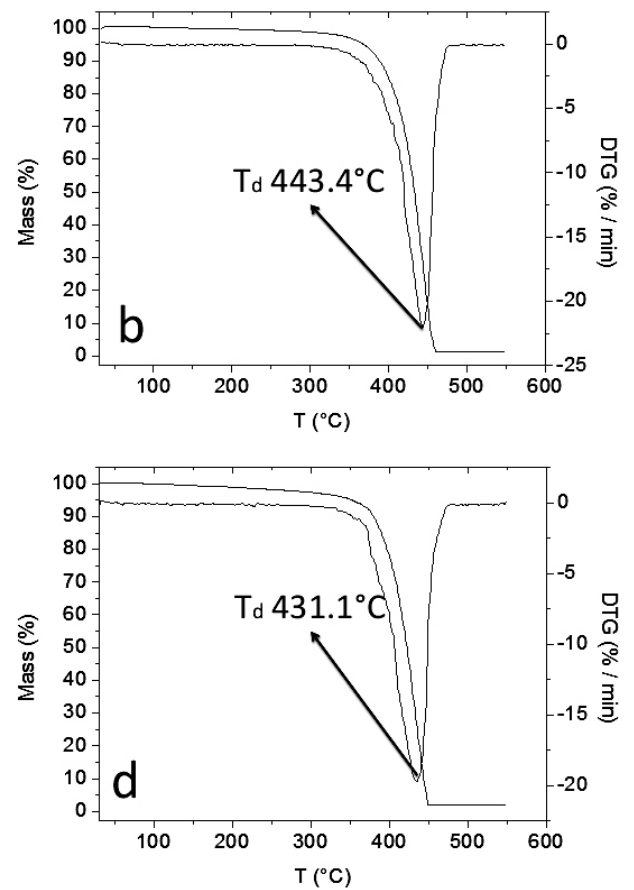

Figure 6. Thermogravimetric analysis (TGA) of the modified IPNs and unmodified MPP membranes. a. MPP. b. M13Naplasma. c. M4Cl. d. M7Clplasma.

Figure $6 \mathrm{~b}$ shows the thermal decomposition of the M13Naplasma membrane, produced in the range between $220^{\circ} \mathrm{C}$ to $340^{\circ} \mathrm{C}$. This temperature range corresponds to the decomposition of the sulfonate group and of the aromatic ring ${ }^{53,54}$. The residual mass percentage was $1.46 \%$, higher than the
MPP value.

Figures $6 \mathrm{c}$ and $6 \mathrm{~d}$ show the thermal decomposition of the $\mathrm{M} 4 \mathrm{Cl}$ and M7Clplasma membranes, produced in the range between $310^{\circ} \mathrm{C}$ to $380^{\circ} \mathrm{C}$. The temperature ranges correspond to the decomposition of the quaternary 
ammonium group and of the aromatic ring ${ }^{55,56}$. The residual mass percentage was $1.4 \%$ for the $\mathrm{M} 4 \mathrm{Cl}$ and $1.9 \%$ for the $\mathrm{M} 7 \mathrm{Clplasma}$. The residual mass percentage values are higher than the MPP value.

The cationic and anionic IPNs produce a thermal resistance of the MPP membranes because the decomposition temperature $\left(\mathrm{T}_{\mathrm{d}}\right)$ value (M13Naplasma, $\mathrm{M} 4 \mathrm{Cl}$ and M7Clplasma) was increased to a point higher than the ( $\left.\mathrm{T}_{\mathrm{d}}\right)$ of the MPP.

3.4 Determination of membrane mass transport coefficient for $\mathrm{Cr}(\mathrm{VI})$ and $\mathrm{Cr}(\mathrm{III})$ ion transport evaluation.
The membrane capacity permeability for $\mathrm{Cr}(\mathrm{VI})$ ions through $\mathrm{P}(\mathrm{ClVBTA})$ IPNs, semi-IPNs and PP membranes was determined. The percent modification effects on the permeability, together with an acidic $\mathrm{pH}$ medium and a basic $\mathrm{pH}$ medium have been investigated.

The mass transport coefficient values decreased from M4Cl.PEI $\left(11.0 \times 10^{-6}\right.$ $\left.\mathrm{m} \mathrm{s}^{-1}\right)>\operatorname{M} 6 \mathrm{ClP}\left(6.60 \times 10^{-6} \mathrm{~m} \mathrm{~s}^{-1}\right)>$ M7Clplasma.PEI $\left(5.25 \times 10^{-6} \mathrm{~m} \mathrm{~s}^{-1}\right)>\mathrm{M} 3 \mathrm{Cl}$ $\left(4.15 \times 10^{-6} \mathrm{~m} \mathrm{~s}^{-1}\right)>$ M6ClP.PEI $\left(3.76 \times 10^{-6} \mathrm{~m} \mathrm{~s}^{-1}\right)>$ M7Clplasma $\left(2.32 \times 10^{-6} \mathrm{~m}\right.$ $\left.\mathrm{s}^{-1}\right)>\operatorname{MPP}\left(0.35 \times 10^{-6} \mathrm{~m} \mathrm{~s}^{-1}\right)$ at $\mathrm{pH} 3.0$. The M7Clplasma membrane exhibited a lower mass transport coefficient value (as determined by the injection method) than the membranes containing P(CIVBTA) (IPN)s.
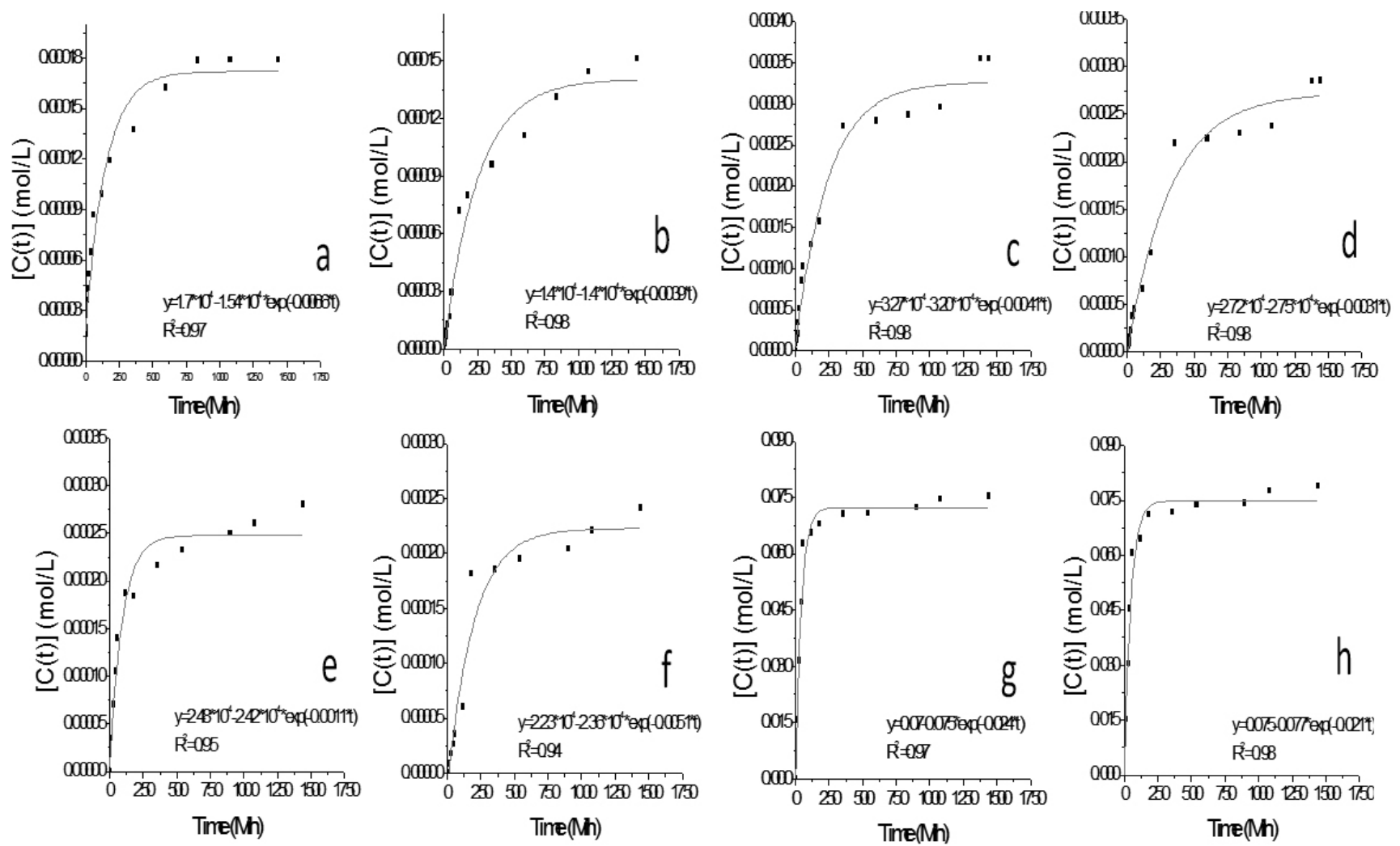

Figure7.Cr(VI) extraction profile. At pH 3.0: a. M4Cl.PEI, b. M6ClP. At pH 9.0: c. M7Clplasma, d. M7Clplasma.PEI. Extraction profile for binary system at pH 9.0 for $\mathrm{Cr}(\mathrm{VI})$ ions, e. M3Cl.PEI, f. M6Cl.P. For $\mathrm{NO}_{3}^{-}$ions, g. M3Cl.PEI, h. M3Cl.

Some values are shown in Table 4. Figure 7a shows the $\mathrm{Cr}(\mathrm{VI})$ concentration profile by the M4Cl.PEI membrane, and Figure $6 \mathrm{~b}$ shows the M6ClP in the extraction cell. The red line indicates the mathematical exponential non-linear curve fit for both membranes. The Donnan equilibrium was achieved after $500 \mathrm{~min}$ by the M4Cl.PEI and after $875 \mathrm{~min}$ by the M6ClP. The PEI was absorbed on the surface of the membrane to form a monolayer ${ }^{57}$. The membranes with the PEI layer achieved values higher than the values for the P(ClVBTA) IPN membranes without a PEI superficial layer. At a $\mathrm{pH}$ of 3.0, $\mathrm{Cr}(\mathrm{VI})$ exists mainly in the form of $\mathrm{HCrO}_{4}^{-}$at $5.0 \times 10^{-4} \mathrm{~mol} \mathrm{~L}^{-1}$ and under these conditions, the PEI monolayer becomes charged with a hydrogen ion that reinforces the $\mathrm{Cr}(\mathrm{VI})$ ion interactions with the cationic groups. The PEI monolayer obstructs the smallest pores and partially obstructs the pores due to the electrostatic repulsion between the protonated amines and the quaternary ammonium groups ${ }^{57}$.

$\mathrm{Cr}(\mathrm{VI})$ ion transport under such conditions depends on the P(ClVBTA) network concentration inside the pores because at an acid $\mathrm{pH}$, the influence of thepercent modification is mainly due to the variation of the porosity. In the same way, a strong quaternary ammonium group (P(ClVBTA) networks and PEI protonated) interacts with the $\mathrm{Cr}(\mathrm{VI})$ ions, which decreases the ion transport velocity and increases the ion exchange relationship ${ }^{57}$.

Mass transport coefficient values at $\mathrm{pH} 9.0$ decrease in the order $\mathrm{M} 3 \mathrm{Cl} \%$ $\left(14.4 \times 10^{-6} \mathrm{~m} \mathrm{~s}^{-1}\right)>$ M7Clplasma $\left(6.86 \times 10^{-6} \mathrm{~m} \mathrm{~s}^{-1}\right)>$ M7Clplasma.PEI $\left(5.15 \times 10^{-6}\right.$ $\left.\mathrm{m} \mathrm{s}^{-1}\right)>$ M4Cl.PEI $\left(3.93 \times 10^{-6} \mathrm{~m} \mathrm{~s}^{-1}\right)>$ M6ClP $\left(2.03 \times 10^{-6} \mathrm{~m} \mathrm{~s}^{-1}\right)>$ M6ClP.PEI $\left(0.95 \times 10^{-6} \mathrm{~m} \mathrm{~s}^{-1}\right)>\mathrm{MPP}\left(0.79 \times 10^{-6} \mathrm{~m} \mathrm{~s}^{-1}\right)$. At a pH of 9.0 , most of the $\mathrm{Cr}(\mathrm{VI})$ ions are $\mathrm{CrO}_{4}^{2-}$. The high concentration of the initial monomer membrane $(\mathrm{M} 3 \mathrm{Cl} \%)$ and the plasma membrane exhibited a higher mass transport coefficient value than the other membranes containing P(CIVBTA) (IPN)s. Some values are shown in Table 4. Figure $7 \mathrm{c}$ shows the $\mathrm{Cr}(\mathrm{VI})$ concentration profile of the M7Clplasma membrane, and Figure 7d shows the M7Clplasma. PEI in the extraction cell. The red line indicates the mathematical exponential non-linear curve fit by both membranes. The Donnan equilibrium was achieved after 700 min by the M7Clplasma and after 1000 min by the M7Clplasma.PEI. PEI at $\mathrm{pH} 9.0$ was not protonated, and produced a chelating effect due to the concentration gradient when the $\mathrm{Cr}(\mathrm{VI})$ ions and quaternary ammonium groups or $\mathrm{Cr}(\mathrm{VI})$ ions and amine groups interacted during the diffusion. The $\mathrm{Cr}(\mathrm{VI})$ ions compete against hydroxyl ions during ion exchanges within the membrane with the quaternary ammonium group $\mathrm{P}(\mathrm{ClVBTA})$ networks.

The $\mathrm{Cr}(\mathrm{VI})$ ion at $\mathrm{pH} 9.0$ yielded a higher mass transfer coefficient value than at $\mathrm{pH}$ 3.0. At acid $\mathrm{pH}$, the $\mathrm{Cr}(\mathrm{VI})$ ions and the $\mathrm{P}(\mathrm{ClVBTA}) \mathrm{IPN}$ membranes, and P(CIVBTA) IPNs + PEI layer membranes are in their ionized forms, resulting in the retention of the $\mathrm{Cr}(\mathrm{VI})$ through the membranes by the strong ionic interactions. At basic $\mathrm{pH}$, the $\mathrm{Cr}(\mathrm{VI})$ ions are ionized, but the P(CIVBTA) IPN membranes and the P(CIVBTA) IPNs + PEI layer membranes are in the partially ionized form. Thus, the transport of $\mathrm{Cr}(\mathrm{VI})$ is accelerated by the partially ionized P form (CIVBTA) IPN membranes due to the chelating effect and the electrostatic force. The Stokes radii hydration of $\mathrm{Cr}(\mathrm{VI})$ at $\mathrm{pH}$ 
$3.0\left(\mathrm{HCrO}_{4}^{-}, 0.375 \mathrm{~nm}\right)$ and $\mathrm{pH} 9.0\left(\mathrm{CrO}_{4}^{2-}, 0.240 \mathrm{~nm}\right)$ produces one effect in the transport through the membranes because the size difference causes friction during the movement and a strong electrostatic force during the ion exchange. All of these features produce a retention effect.

A binary system of $\mathrm{Cr}(\mathrm{VI}) / \mathrm{NO}_{3}{ }^{-}$in the mass transport through the IPN membranes was analyzed. The extraction reagent was $1 \mathrm{~mol} \mathrm{~L}^{-1} \mathrm{NaCl}$. The mass transport coefficient values of the $\mathrm{Cr}(\mathrm{VI})$ in the binary system decreased in order $\mathrm{M} 3 \mathrm{Cl}\left(21.0 \times 10^{-6} \mathrm{~m} \mathrm{~s}^{-1}\right)>\mathrm{M} 3 \mathrm{Cl}$.PEI $\left(17.7 \times 10^{-6} \mathrm{~m} \mathrm{~s}^{-1}\right)>\operatorname{M} 6 \mathrm{ClP}\left(8.6 \times 10^{-6}\right.$ $\left.\mathrm{m} \mathrm{s}^{-1}\right)>$ M4Cl.PEI $\left(8.1 \times 10^{-6} \mathrm{~m} \mathrm{~s}^{-1}\right)>$ M6ClP.PEI $\left(7.8 \times 10^{-6} \mathrm{~m} \mathrm{~s}^{-1}\right)>$ M7Clplasma. PEI $\left(4.3 \times 10^{-6} \mathrm{~m} \mathrm{~s}^{-1}\right)>$ M7Clplasma $\left(3.2 \times 10^{-6} \mathrm{~m} \mathrm{~s}^{-1}\right)>\mathrm{M} 4 \mathrm{Cl}\left(2.5 \times 10^{-6} \mathrm{~m} \mathrm{~s}^{-1}\right)$ at $\mathrm{pH}$ 9.0. Figure $7 \mathrm{e}$ shows the $\mathrm{Cr}(\mathrm{VI})$ concentration profile of the $\mathrm{M} 3 \mathrm{Cl}$. PEI membrane, and Figure $7 \mathrm{f}$ shows the M6ClP in the extraction cell. The red line indicates the mathematical exponential non-linear curve fit by both membranes. The Donnan equilibrium was achieved after $300 \mathrm{~min}$ by the $\mathrm{M} 3 \mathrm{Cl}$. PEI and after $625 \mathrm{~min}$ by the M6ClP.

The mass transport coefficient values of the $\mathrm{NO}^{3-}$ in the binary system decreased in the order M3Cl.PEI $\left(39.8 \times 10^{-6} \mathrm{~m} \mathrm{~s}^{-1}\right)>\mathrm{M} 3 \mathrm{Cl}\left(35.1 \times 10^{-6} \mathrm{~m} \mathrm{~s}^{-1}\right)$ $>\mathrm{M} 4 \mathrm{Cl}\left(13.6 \times 10^{-6} \mathrm{~m} \mathrm{~s}^{-1}\right)>\operatorname{M} 6 \mathrm{ClP}\left(10.4 \times 10^{-6} \mathrm{~m} \mathrm{~s}^{-1}\right)>\operatorname{M} 6 \mathrm{ClP}$.PEI $\left(9.7 \times 10^{-6} \mathrm{~m}\right.$ $\left.\mathrm{s}^{-1}\right)>$ M7Clplasma $\left(6.9 \times 10^{-6} \mathrm{~m} \mathrm{~s}^{-1}\right)>$ M7Clplasma.PEI $\left(5.8 \times 10^{-6} \mathrm{~m} \mathrm{~s}^{-1}\right)>\mathrm{M} 4 \mathrm{Cl}$. PEI $\left(1.1 \times 10^{-6} \mathrm{~m} \mathrm{~s}^{-1}\right)$ at $\mathrm{pH} 9.0$. Figure $7 \mathrm{~g}$ shows the $\mathrm{NO}_{3}-$ concentration profile of the $\mathrm{M} 3 \mathrm{Cl} . \mathrm{PEI}$ membrane, and Figure $7 \mathrm{~h}$ shows the $\mathrm{M} 3 \mathrm{Cl}$ in the extraction cell. The red line indicates the mathematical exponential non-linear curve fit by both membranes. The Donnan equilibrium was achieved after $125 \mathrm{~min}$ by both membranes.

These results may be due to the differences between the Stokes radii and the Gibbs free-energy for hydration $\left(\mathrm{NO}_{3}^{-}, 0.2 \mathrm{~nm}\right.$ and $\left.\mathrm{CrO}_{4}^{2-}, 0.240 \mathrm{~nm}\right)$. The $\mathrm{NO}^{3}$ - ions are smaller and less hydrated than the CrO42- ion, which provides more movement through the membranes. The quaternary ammonium groups preferred the $\mathrm{CrO}_{4}^{2-}$ ions because they are divalent and need a greater quantity of charge-fixed groups.

The capacity permeability for $\mathrm{Cr}(\mathrm{III})$ ions through $\mathrm{P}(\mathrm{SSNa}) \mathrm{IPN}$, semiIPN, P(SSNa) IPN plus PVA layer, and unmodified MPP membranes was determined. The $\mathrm{Cr}(\mathrm{III})$ concentration is suitable for interacting with the fixed charges in the membrane ${ }^{34}$. $\mathrm{Cr}(\mathrm{III})$ can exist in the forms $\mathrm{CrOH}^{2+}$ and $\mathrm{Cr}(\mathrm{OH})_{2}^{+}$ at $4.0 \times 10^{-2}\left(\mathrm{~mol} \mathrm{~L}^{-1}\right)^{58,59}$. The acidity guarantees the total dissolution and $\mathrm{Cr}(\mathrm{III})$ ionization, avoiding theformation of metallic hydroxyls ${ }^{60}$.
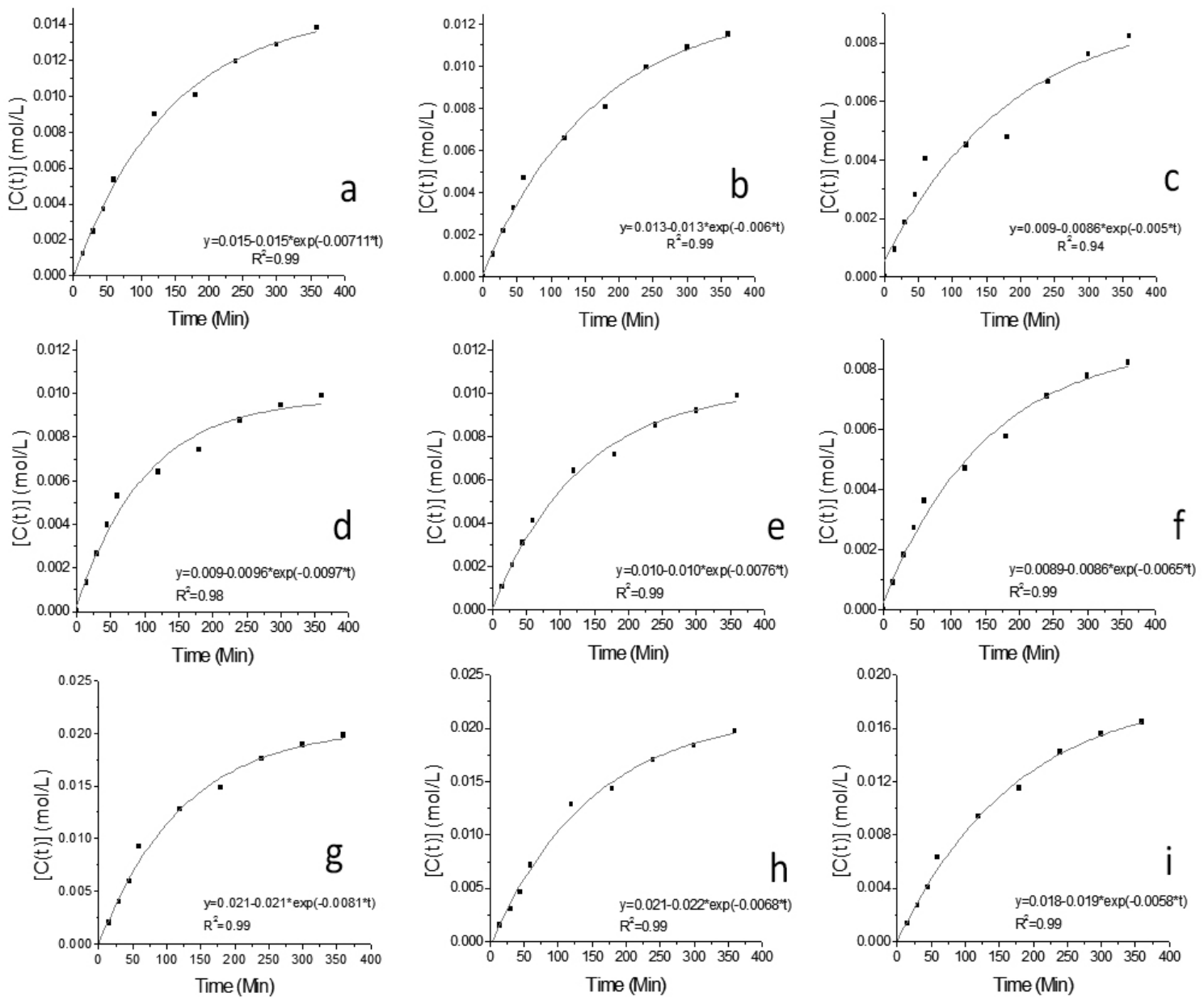

Figure 8. Cr(III) extraction profile. The extractor agent was $1 \times 10^{-1} \mathrm{~mol} \mathrm{~L}^{-1} \mathrm{HNO}_{3}$, with a $\mathrm{Cr}(\mathrm{III})$ food concentration of $4.0 \times 10^{-2} \mathrm{~mol} \mathrm{~L} \mathrm{~L}^{-1} \mathrm{Cr}(\mathrm{III}) \mathrm{with} \mathrm{pH} 2.0$. a. M13Naplasma, b. M12NaP. c. M9Na.At pH 2.0 and $4.0 \times 10^{-2} \mathrm{~mol} \mathrm{~L}^{-1} \mathrm{Cr}(\mathrm{III})$ in the food chamber, the extractor agent was $1 \times 10^{-3} \mathrm{~mol} \mathrm{~L}^{-1} \mathrm{HNO}_{3}$. d. M9Na.PVA. e. M13Naplasma. f. M12NaP. At pH 2.0 with $4.0 \times 10^{-2} \mathrm{~mol} \mathrm{~L}^{-1} \mathrm{Cr}(\mathrm{III})$ in the food chamber, using a mixture of $1 \times 10^{-2} \mathrm{~mol} \mathrm{~L}^{-1} \mathrm{HNO}_{3}$ and $1 \mathrm{~mol} \mathrm{~L}^{-1} \mathrm{NaCl}^{3}$ as the extractor. g. M9Na.PVA. h. M13Naplasma. i. M12NaP.

The mass transport coefficient values decreased from M13Naplasma $\left(11.9 \times 10^{-6} \mathrm{~m} \mathrm{~s}^{-1}\right)>\operatorname{M} 12 \mathrm{NaP}\left(10.1 \times 10^{-6} \mathrm{~m} \mathrm{~s}^{-1}\right)>$ M9Na $\left(8.95 \times 10^{-6} \mathrm{~m} \mathrm{~s}^{-1}\right)>$ M12NaP.PVA $\left(8.62 \times 10^{-6} \mathrm{~m} \mathrm{~s}^{-1}\right)>$ M8Na $\left(8.18 \times 10^{-6} \mathrm{~m} \mathrm{~s}^{-1}\right)>$ M11NaP.PVA $\left(1.44 \times 10^{-6} \mathrm{~m} \mathrm{~s}^{-1}\right)>\operatorname{MPP}\left(0.1 \times 10^{-6} \mathrm{~m} \mathrm{~s}^{-1}\right)$ at $\mathrm{pH} 1.0$. The extractor agent was $1 \times 10^{-1} \mathrm{~mol} \mathrm{~L}^{-1} \mathrm{HNO}_{3}$. These results may depend on the strong ionic interactions between the $\mathrm{Cr}(\mathrm{III})$ ions and the membrane sulfonate groups. The porosity did not decrease in the superficial PVA layer. The PVA was adsorbed on the membrane surface to form a monolayer ${ }^{57}$. Some values are shown in Table 4. Figure 8a shows the $\mathrm{Cr}(\mathrm{III})$ concentration profile in the M13Naplasma membrane. Figure $8 \mathrm{~b}$ shows the M12NaP, and Figure $8 \mathrm{c}$ shows the M9Na, in the extraction cell. The Donnan equilibrium was obtained after $300 \mathrm{~min}$. The red line indicates the mathematical exponential non-linear curve fit by both membranes.

At $\mathrm{pH} 2.0$ and $4.0 \times 10^{-2} \mathrm{~mol} \mathrm{~L}^{-1} \mathrm{Cr}$ (III) in the food chamber, the mass 
transport coefficient values decreased from M9Na.PVA $\left(16.3 \times 10^{-6} \mathrm{~m} \mathrm{~s}^{-1}\right)$ $>$ M13Naplasma $\left(12.7 \times 10^{-6} \mathrm{~m} \mathrm{~s}^{-1}\right)>\operatorname{M} 12 \mathrm{NaP}\left(10.9 \times 10^{-6} \mathrm{~m} \mathrm{~s}^{-1}\right)>\mathrm{M} 8 \mathrm{Na}$ $\left(10.1 \times 10^{-6} \mathrm{~m} \mathrm{~s}^{-1}\right)>$ M12NaP.PVA $\left(9.18 \times 10^{-6} \mathrm{~m} \mathrm{~s}^{-1}\right)>$ M9Na $\left(8.86 \times 10^{-6} \mathrm{~m}\right.$ $\left.\mathrm{s}^{-1}\right)>\operatorname{MPP}\left(0.5 \times 10^{-6} \mathrm{~m} \mathrm{~s}^{-1}\right)$, and the extractor agent was $1 \times 10^{-3} \mathrm{~mol} \mathrm{~L}^{-1} \mathrm{HNO}_{3}$. The PVA improved the hydrophilicity of the $\mathrm{P}(\mathrm{SSNa})$ network membranes. The $\mathrm{pH} 3.0$ produces a higher pass of the $\mathrm{Cr}(\mathrm{III})$ through the IPN membranes than $\mathrm{pH}$ 1.0. Figure $8 \mathrm{~d}$ shows the $\mathrm{Cr}(\mathrm{III})$ concentration profile in the M9Na. PVA membrane, Figure 8e shows the M13Naplasma, and Figure 8f shows the $\mathrm{M} 12 \mathrm{NaP}$ in the extraction cell. The Donnan equilibrium was obtained after 250 min by the M8Na.PVA, and after 300 min by the M13Naplasma and M12NaP. The red line indicates the mathematical exponential non-linear curve fit by both membranes.

The low $\mathrm{pH}$ in the extractor solution may exchange with the $\mathrm{Cr}(\mathrm{III})$ ions more rapidly and stimulates diffusion of both ions due to the concentration gradient $^{61,62}$. However, the mass transport coefficient is higher in the $\mathrm{pH} 3.0$ extractor solution than in the $\mathrm{pH} 1.0$ extractor solution.

At $\mathrm{pH} 2.0$ with $4.0 \times 10^{-2} \mathrm{~mol} \mathrm{~L}^{-1} \mathrm{Cr}$ (III) in the food chamber and using a mixture of $1 \times 10^{-2} \mathrm{~mol} \mathrm{~L}^{-1} \mathrm{HNO}_{3}$ and $1 \mathrm{~mol} \mathrm{~L}^{-1} \mathrm{NaCl}$ as the extractor as the extractor, the mass transport coefficient values decreased from M8Na.PVA $\left(13.4 \times 10^{-6} \mathrm{~m} \mathrm{~s}^{-1}\right)>$ M13Naplasma $\left(11.3 \times 10^{-6} \mathrm{~m} \mathrm{~s}^{-1}\right)>\operatorname{M} 12 \mathrm{NaP}\left(9.62 \times 10^{-6} \mathrm{~m} \mathrm{~s}^{-1}\right)$ $>$ M 8 Na. $\left(8.28 \times 10^{-6} \mathrm{~m} \mathrm{~s}^{-1}\right)>$ M12NaP.PVA $\left(8.27 \times 10^{-6} \mathrm{~m} \mathrm{~s}^{-1}\right)>$ M9Na $\left(7.76 \times 10^{-}\right.$ $\left.{ }^{6} \mathrm{~m} \mathrm{~s}^{-1}\right)>$ MPP $\left(0.1 \times 10^{-6} \mathrm{~m} \mathrm{~s}^{-1}\right)$. Figure $8 \mathrm{~g}$ shows the $\mathrm{Cr}(\mathrm{III})$ concentration profile in the M8Na.PVA membrane, the Figure 8h shows the M13Naplasma, and Figure $8 \mathrm{i}$ shows the $\mathrm{M} 12 \mathrm{NaP}$ in the extraction cell. The Donnan equilibrium was obtained after $275 \mathrm{~min}$ by the M8Na.PVA and after $300 \mathrm{~min}$ by the M13Naplasma and M12NaP. The red line indicates the mathematical exponential non-linear curve fit by both membranes. The $\mathrm{H}^{+}(0.030 \mathrm{~nm}$ in size $)$ ion has a higher movement capacity during the membrane phase because of its small size relative to the $\operatorname{Cr}(\mathrm{III})(0.062 \mathrm{~nm}$ in size $)$. This mixture did not improve the $\mathrm{Cr}(\mathrm{III})$ transport relative to using $\mathrm{HNO}_{3}$ alone at $\mathrm{pH}$ 3.0. The high sodium ion concentration in the extractor mixture may exchange with the $\mathrm{Cr}(\mathrm{III})$ ions and stimulate ion diffusion due to the concentration gradient ${ }^{61,62}$, but this exchange did not occur.

The test at $\mathrm{pH} 1$.0with a mixture of $1 \times 10^{-2} \mathrm{~mol} \mathrm{~L}^{-1} \mathrm{HNO}_{3}$ and $1 \mathrm{~mol}$ $\mathrm{L}^{-1} \mathrm{NaCl}$ as the extractor reagent produces a retention effect in the P(SSNa) IPN membranes because the mass transport coefficients are lower than the test at $\mathrm{pH}$ 3.0. The test at $\mathrm{pH} 3.0$ produced a Donnan transport through the P(SSNa) IPN membranes with ahighermasstransportcoefficient.

\section{CONCLUSIONS}

Microporous $\mathrm{P}(\mathrm{ClVBTA})$ and $\mathrm{P}(\mathrm{SSNa})$ interpenetrating polymer networks (IPNs) polypropylene membranes with ion exchange capacities can be obtained using radical polymerization. The control of the functional network density was made by the functional monomer and crosslinked MBA concentrations.

The P(CIVBTA) and P(SSNa) IPN membranes were tested via ATR/ FT-IR, SEM, DRX, TGA, and their hydrophilicity with the mass transport coefficient. These results demonstrated the IPNs form within the pores.

The transport properties for the $\mathrm{Cr}(\mathrm{VI})$ at $\mathrm{pH} 3.0, \mathrm{pH} 9.0$, and in a binary system of $\mathrm{Cr}(\mathrm{VI}) / \mathrm{NO}_{3}^{-}$was evaluated using the Donnan dialysis principle. The mass transport coefficient was determinate by non-lineal curve fit of the experimental date. The M4Cl.PEI membrane was selected because the obtained $\mathrm{Cr}(\mathrm{VI})$ ions mass transport coefficient results $\left(11.0 \times 10^{-6} \mathrm{~m} \mathrm{~s}^{-1}, \mathrm{R}^{2} 0.97\right)$ were used at $\mathrm{pH}$ 3.0. The M7Clplasma membrane was selected due to its transport capacity $\left(6.86 \times 10^{-6} \mathrm{~m} \mathrm{~s}^{-1}, \mathrm{R}^{2} 0.98\right)$ for $\mathrm{Cr}(\mathrm{VI})$ ions at $\mathrm{pH} 9.0$. And, the $\mathrm{M} 3 \mathrm{Cl}$. PEI membrane was selected due to its transport velocity $\left(21.0 \times 10^{-6} \mathrm{~m} \mathrm{~s}^{-1}, \mathrm{R}^{2}\right.$ $0.97)$ for $\mathrm{Cr}(\mathrm{VI})$ ions at $\mathrm{pH} 9.0$ in a binary system.

Besides, the transport properties for the $\mathrm{Cr}(\mathrm{III})$ ions at $\mathrm{pH} 1.0, \mathrm{pH} 3.0$, and a mixture of $1 \times 10^{-2} \mathrm{~mol} \mathrm{~L}^{-1} \mathrm{HNO}_{3}$ and $1 \mathrm{~mol} \mathrm{~L}^{-1} \mathrm{NaCl}$ as the extracting reagent was evaluated using the Donnan dialysis principle. The M13Naplasma $\left(11.9 \times 10^{-6} \mathrm{~m} \mathrm{~s}^{-1}, \mathrm{R}^{2} 0.99\right)$ was selected for the $1 \times 10^{-1} \mathrm{~mol} \mathrm{~L}^{-1} \mathrm{HNO}_{3}$ extraction reagent, the M9Na.PVA $\left(16.3 \times 10^{-6} \mathrm{~m} \mathrm{~s}^{-1}, \mathrm{R}^{2} 0.98\right)$ was selected for the $1 \times 10^{-3}$ mol L ${ }^{-1} \mathrm{HNO}_{3}$ extraction reagent, and the M8Na.PVA $\left(13.4 \times 10^{-6} \mathrm{~m} \mathrm{~s}^{-1}, \mathrm{R}^{2} 0.99\right)$ membrane was selected when the extraction agent was a $1 \times 10^{-2} \mathrm{~mol} \mathrm{~L}^{-1} \mathrm{HNO}_{3}$ and $1 \mathrm{~mol} \mathrm{~L}^{-1} \mathrm{NaCl}$ mixture .

The $\mathrm{Cr}(\mathrm{VI})$ and $\mathrm{Cr}(\mathrm{III})$ extraction results were also important because the starting material was initially hydrophobic, and the wetting properties improved upon modification.

\section{ACKNOWLEDGMENTS}

The authors thank the FONDECYT (Project No 1110079), PIA (Anillo ACT-130), REDOC (MINEDUC Project UCO1202 at U. de Concepción),
7FP-MC Actions Grant, CHILTURPOL2 (PIRSES-GA-2009 Project, Grant No: 269153), and Marie Curie Program. Julio Sánchez thanks FONDECYT N ${ }^{\circ}$ 11140324 instead of postdoctoral Grant No. 3120048 and CIPA, Chile.

\section{REFERENCES}

1. M. E. I. Ahmed, Eleventh International Water Technology Conference, 233-250 (2007).

2. M. Owlad, M. K. Aroua, W. A. W. Daudand S. Baroutian, Water, Air, and Soil Pollution, 200, 59-77 (2009).

3. K. D. Mielenz, R. Velapoldiand R. Mavrodineanu, Standardization in Spectrophotometry and Luminescence Measurements: Proceedings of a Workshop Seminar Held at the National Bureau of Standards, Gaithersburg, Maryland, November, November 19-20, 1975, US Department of Commerce, National Bureau of Standards, 1976.

4. B.L. Rivas, S.A. Pooley, M. Luna, Macromol Rapid Commun, 21, 905908 (2000).

5. WHO. World Health Organization, Genova, 2008.

6. G.-R. Refugio Bernardo, R.-M. Jose Reneand A.-D. 1. T. Ma Catalina, $J$ Hazard Mater, 170, 845-854 (2009).

7. F. C. Richardand A. Bourg, Water Res, 25, 807-816 (1991).

8. A. Golder, A. Samantaand S. Ray, Sep Purifi Technol, 53, 33-41 (2007).

9. R. R. Patterson, S. Fendorfand M. Fendorf, Environ Sci Technol, 31, 2039-2044 (1997).

10. D. Park, S.-R. Lim, Y.-S. Yunand J. M. Park, Chemosphere, 70, 298-305 (2007).

11. G. Arslanand E. Pehlivan, Bioresource Technol, 98, 2836-2845 (2007).

12. K.E. Geckeler, R. Zhou, B.L. Rivas, Angew Makromol Chem, 197, $107-$ 115 (1992).

13. B.L. Rivas, E. Pereira, R. Cid., J Appl Polym Sci, 95, 1091-1099 (2005).

14. S. Nataraj, K. Hosamaniand T. Aminabhavi, Desalination, 217, 181-190 (2007).

15. P. Venkateswaranand K. Palanivelu, Hydrometallurgy, 78, 107-115 (2005).

16. A. Bhowaland S. Datta,J Membrane Sci, 188, 1-8 (2001).

17. E. H. Cwirkoand R. G. Carbonell,J Membrane Sci, 48, 155-179 (1990)

18. A. Tor, Y. Çengeloğlu, M. Ersövand G. Arslan, Desalination, 170, 151159 (2004).

19. A. Narębskaand M. Staniszewski, Separ Sci Technol, 43, 490-501 (2008).

20. A. Zheleznov, D. Windmöller, S. Körnerand K. Böddeker,J Membrane Sci, 139, 137-143 (1998).

21. J. Mathur, M. Murali, M. B. Krishna, V. Ramachandhran, M. Hanraand B. Misra, JRadioanal Nucl Ch, 232, 237-240 (1998).

22. A. A. Said, M. Amaraand H. Kerdjoudj, Ionics, 19, 177-183 (2013).

23. Y. S. Dzyazko, S. L. Vasilyuk, L. M. Rozhdestvenskaya, V. N. Belyakov, N. V. Stefanyak, N. Kabay, M. Yüksel, Ö. Ararand Ü. Yüksel, Chem Eng Commun, 196, 22-38 (2008).

24. E. Castillo, M. Granadosand J. L. Cortina, J Chromatogr A,963, 205-211 (2002).

25. E. Castillo, M. Granadosand J. L. Cortina, Anal Chim Acta, 464, 15-23 (2002).

26. P. Thapliyal, Compos Interface, 17, 85-89 (2010).

27. L. Chikh, V. Delhorbeand O. Fichet,J Membrane Sci, 368, 1-17 (2011).

28. J. H. Duffus, M. Nordbergand D. M. Templeton, Pure Appl Chem, 79 , 1153-1344 (2007)

29. B. Gladand K. Irgum,J Membrane Sci, 101, 53-59 (1995).

30. C.-Y. Tseng, Y.-S. Ye, K.-Y. Kao, J. Joseph, W.-C. Shen, J. Rickand B.-J Hwang, Int J Hydrogen Energ, 36, 11936-11945 (2011).

31. J. Qiao, J. Fu, L. Liu, Y. Liuand J. Sheng, Int J Hydrogen Energ, 37, 4580-4589 (2012)

32. H. Wang, C. Wu, Y. Wu, J. Luoand T. Xu,J Membrane Sci, 376, 233-240 (2011).

33. M. Bryjakand I. Duraj, Desalination, 310, 39-42 (2013).

34. A. Tor, J Hazard Mater, 141, 814-818 (2007).

35. O. Thomasand C. Burgess, UV-visible Spectrophotometry of Water and Wastewater, Elsevier, 2007.

36. D. Y. Xinyuan Zhu, Hongxi Yao and Pingfang Zhu, Macromol Rapid Comm, 21, 354-357 (2000).

37. E. Pretsch, P. Bühlmann, C. Affolter, E. Pretsch, P. Bhuhlmannand C. Affolter, Structure Determination of Organic Compounds, Springer, 2000.

38. M. Ulbricht, Polymer, 47, 2217-2262 (2006).

39. H. Matsuyama, M. Yuasa, Y. Kitamura, M. Teramotoand D. R. Lloyd, $J$ 
Membrane Sci, 179, 91-100 (2000).

40. F. Yañez, A. Concheiroand C. Alvarez-Lorenzo, Eur J Pharm biopharma, 69, 1094-1103 (2008).

41. J. Hu, U. Schulzeand J. Pionteck, Polymer, 40, 5279-5284 (1999).

42. K. Huand J. M. Dickson,J Membrane Sci, 301, 19-28 (2007).

43. A. Anžlovarand M. Žigon, J Polym Sci Pol Phys, 40, 115-123 (2002).

44. L. Zhang, M. Panand J. Zhang, J Appl Polym Sci, 91, 1168-1173 (2004).

45. I. S. M. T. Maddanimath, S.R. Sainkar, K. Vijayamohanan, K.I Shaikh, Patil, and S. P. Vernekar, Sensor Actuat B, 81, 141-151 (2002).

46. C.-c. Wang, F.-1. Yang, L.-F. Liu, Z.-m. Fuand Y. Xue,J Membrane Sci, 345, 223-232 (2009).

47. Y.-F. Yang, L.-S. Wanand Z.-K. Xu,J Membrane Sci, 326, 372-381 (2009).

48. F. G. Ramos Filho, T. J. A. Mélo, M. S. Rabelloand S. M. Silva, Polym degrad stabil, 89, 383-392 (2005)

49. J. Villaluenga, M. Khayet, M. Lopez-Manchado, J. Valentin, B. Seoaneand J. Mengual, Eur Polym J, 43, 1132-1143 (2007).

50. T. Maddanimath, I. Mulla, S. Sainkar, K. Vijayamohanan, K. Shaikh, A. Patiland S. Vernekar, Sensor Actuat B: Chem, 81, 141-151 (2002).

51. J. Golebiewskiand A. Galeski, Compos Sci Technol, 67, 3442-3447
(2007).

52. B. Bae, B.-H. Chunand D. Kim, Polymer, 42, 7879-7885 (2001).

53. C.-E. Tsai, C. Lin, J. Rickand B.-J. Hwang, J Power Sources, 196, 5470$5477(2011)$

54. Y. Xiong, J. Fang, Q. H. Zengand Q. L. Liu,J Membrane Sci, 311, 319325 (2008).

55. J. Qiao, J. Fu, R. Lin, J. Liuand J. Ma, ECS Transactions, 33, 1915-1922 (2010).

56. J. Fang, Y. Yang, X. Lu, M. Ye, W. Liand Y. Zhang, Int J Hydrogen Energ, 37, 594-602 (2012).

57. T. Sata, Ion exchange membranes: preparation, characterization, modification and application, Royal Society of Chemistry, 2004.

58. C. Fontàs, I. Queraltand M. Hidalgo, Spectrochim Acta B, 61, 407-413 (2006).

59. W. G. Cookand R. P. Olive, Corros Sci, 58, 291-298 (2012).

60. D. Wu, Y. Sui, S. He, X. Wang, C. Liand H. Kong, J Hazard Mater, 155, 415-423 (2008).

61. I. Marzouk, L. Dammak, L. Chaabaneand B. Hamrouni, Am J Anal Chem, 4(2013).

62. Y. Cengeloglu, E. Kir, M. Ersoz, T. Buyukerkekand S. Gezgin, Colloids Surfaces A, 223, 95-101 (2003). 